Zeszyty Naukowe Szkoły Głównej Gospodarstwa Wiejskiego w Warszawie

Problemy Rolnictwa Światowego tom 18 (XXXIII), zeszyt 2, 2018: 44-56

DOI: 10.22630/PRS.2018.18.2.33

Andrzej Czyżewski $^{1}$, Jakub Staniszewski ${ }^{2}$

Uniwersytet Ekonomiczny w Poznaniu

\title{
Dylematy operacjonalizacji paradygmatu zrównoważonego rozwoju rolnictwa $z$ wykorzystaniem pojęcia ekoefektywności
}

\section{Dilemmas of the Operationalisation of the Sustainable Agriculture Development Paradigm with Eco-Efficiency Measures}

\begin{abstract}
Synopsis. W artykule poruszony zostaje problem metodycznych uwarunkowań operacjonalizacji paradygmatu zrównoważonego rozwoju rolnictwa z wykorzystaniem koncepcji ekoefektywności i metody obwiedni danych, DEA. Na podstawie przeglądu literatury zidentyfikowano dylematy przed jakimi staje badacz przyjmujący te perspektywę badawczą. Choć zastosowanie omawianych metod pozwala na ograniczenie problemów związanych $\mathrm{z}$ doborem wag i punktu odniesienia, a także różnych jednostek, w których wyrażone są nakłady i efekty działalności rolniczej, wymaga jednocześnie, przyjecia założenia o nieuwzglednianiu w badaniach czynnika losowego i homogeniczności badanej grupy podmiotów, a także o wymienności nakładów kapitałowych i środowiskowych oraz istnieniu instytucjonalnych ograniczeń nadmiernej eksploatacji zasobów ekologicznych.

Słowa kluczowe: rolnictwo, zrównoważona intensyfikacja, ekoefektywność, produktywność środowiskowa, DEA

Abstract. The article discusses the methodical problems of operationalization of the agriculture sustainable development with the use of the eco-efficiency concept and the DEA method. On the basis of the literature review, dilemmas faced by the researcher adopting this research perspective have been identified. Although the application of these methods allows to reduce the problems related to the selection of weights and reference points, as well as various units in which the inputs and effects of agricultural activity are expressed, at the same time it requires the assumption that: 1) the research will not take into account a random factor; 2) the analysed group of entities is homogenous; 3) exists interchangeability of capital and environmental inputs; 4) exist institutional limitations of overexploitation of environmental resources.
\end{abstract}

Key words: agriculture, sustainable intensification, eco-efficiency, environmental productivity, DEA

JEL Classification: Q01, Q56, B41

\section{Wprowadzenie}

Historycznie, produktywne rolnictwo dawało podstawy wzrostu gospodarczego pozostałych sektorów gospodarki, pozwalając na wyżywienie coraz większej liczby ludności (Staniszewski 2017). Jednakże, trzeba mieć świadomość, że choć produktywność

${ }^{1}$ prof. zw. dr hab., Katedra Makroekonomii i Gospodarki Żywnościowej UE w Poznaniu, Al. Niepodległości 10, 61-875 Poznań, e-mail: kmigz@ue.poznan.pl; https://orcid.org/0000-0002-6233-6824

${ }^{2}$ mgr, Katedra Makroekonomii i Gospodarki Żywnościowej UE w Poznaniu, Al. Niepodległości 10, 61-875 Poznań, e-mail: jakub.staniszewski@ue.poznan.pl; https://orcid.org/0000-0001-8074-0911 
rolnictwa stymulowana była wówczas poprawą struktur wytwórczych, jak i postępem technicznym, to i tak jej dynamika znacząco odbiegała od ogólnej dynamiki wzrostu gospodarczego. Z badań Allena (2000) wynika, że nawet w krajach charakteryzujących się najwyższym wzrostem produktywności pracy w rolnictwie w latach 1500-1800, tj. Anglii i Holandii, przyrost wynosił odpowiednio 43\% i 36\%, podczas, gdy szacunkowy przyrost PKB per capita w analogicznym okresie (1500-1820) wynosił odpowiednio 139\% i 142\% (Maddison 2005, s. 25). Jednocześnie zatem spadało znaczenie rolnictwa w gospodarce, początkowo na rzecz handlu, w dalszej perspektywie na rzecz rozwijającego się przemysłu, współcześnie zaś na rzecz usług. Oceniając znaczenie rolnictwa w najbogatszych krajach świata jedynie przez pryzmat udziału tego sektora w kreowaniu PKB, uznać by można, że jest ono marginalne i wciąż maleje. Jak wynika z danych ONZ (2016) w latach 1970-2014 udział rolnictwa, łowiectwa, leśnictwa i rybołówstwa w PKB spadł w Australii z 5,93\% do 2,29\%, w Kanadzie z 4\% do 1,6\%, we Francji z 6,96\% do 1,5\%, w Niemczech z 2,94\% do 0,61\%, w Wielkiej Brytanii z 2,16\% do 0,61\%, zaś w USA z 2,34\% do 1,24\%. Wśród 176 państw, dla których ONZ dysponuje danymi, przeciętnie udział ten spadł natomiast $\mathrm{z}$ $20,1 \%$ do 11,1\%. Dodatkowo, z sektora stanowiącego źródło kapitału i dochodów podatkowych, rolnictwo staje się biorcą transferów publicznych. Zjawisko to nosi nazwę, „paradoksu rozwojowego w polityce rolnej” (Poczta-Wajda 2017). Jak wynika z danych Banku Światowego (2016) w 2011 roku wsparcie rolnictwa najwyższe było w krajach takich jak Japonia (ceny krajowe $80 \%$ wyższe od cen światowych), Norwegia (78\%), Korea Płd. (74\%), Islandia (58\%) i Szwajcaria (53\%). Najmniejsze natomiast m.in. w Ugandzie ($20 \%$ ), Bułgarii $(0,4 \%)$ i Rumunii (2\%). Czy nie oznacza to, że w tych krajach rolnictwo z katalizatora wzrostu, stało się jego przeszkodą? Uznając tradycyjne za wzrost zmiany o charakterze ilościowym, których syntetycznym wyrazem są zmiany wielkości produktu krajowego brutto (Ratajczak 2000, s. 83), a także oceniając sytuację danego kraju jedynie przez pryzmat tego wskaźnika, sektor rolny uznany może zostać za nienadążający za resztą gospodarki, a możliwości jego oddziaływania na poprawę sytuacji ogólnogospodarczej za wyczerpane. Współcześnie jednak istotniejsza jest kategoria rozwoju ekonomicznego, stanowiącego kombinację zmian ilościowych i jakościowych (Ratajczak 2000, s. 83). Szczególnie zaś paradygmat rozwoju zrównoważonego. W tym kontekście, sektor rolny stanowi istotny element systemu warunkującego dalszy rozwój, poprzez dostarczanie szeregu dóbr publicznych i swoisty „nadzór” nad funkcjonowaniem wielu ekosystemów. Kluczem do zrównoważonego rozwoju gospodarki może być zatem zrównoważony rozwój sektora rolnego. Jednakże, choć od lat 80-tych paradygmat zrównoważonego rozwoju zyskuje powszechną akceptację, wraz z jego upowszechnieniem narastają rozbieżności w jego postrzeganiu, co obciąża jednocześnie wszelkie dalsze próby operacjonalizacji. Potrzeba upowszechniania świadomości tych ograniczeń stanowi główną przesłankę tego opracowania. Jego celem jest zebranie najważniejszych wątpliwości rodzących się w obliczu nowego paradygmatu oraz wskazanie jak rzutują one na strategie operacjonalizacji. Jako przykład tej strategii posłużyły badania ekoefektywności. Cel ten realizowany będzie poprzez przegląd literatury. W jego obręb włączone zostały pozycje z trzech obszarów tematycznych. W pierwszej kolejności przedstawiono sposób w jaki teoria zrównoważonego rozwoju przeniesiona zostaje na grunt ekonomicznych badań sektora rolnego. Następnie zebrano informacje dotyczące krytyki tej teorii rozwoju oraz jej cech powodujących szczególne trudności w operacjonalizacji. W końcu, na przykładzie wybranej metody pomiaru ekoefektywności (metoda obwiedni danych, DEA), wskazano jakie rozwiązania zasygnalizowanych problemów proponują badacze. 


\section{Rolnictwo w świetle paradygmatu zrównoważonego rozwoju}

Jak wskazuje Czyżewski B. (2013, s. 60-61) przełożenie koncepcji zrównoważonego rozwoju na grunt ekonomii rolnej jest ewidentne, ze względu na: 1) szczególną rolę jaką czynnik ziemi pełni zarówno w rolnictwie, jak i w zapewnianiu ładu środowiskowego; 2) rolę terenów wiejskich zamieszkiwanych przez większość ludności świata w kształtowaniu ładu ekonomicznego i społecznego; 3) strategiczną rolę żywności, dostarczanej przez sektor rolny, dla zachowania ładu społecznego; 4) strategiczną rolę sektora rolnego powiązaną $\mathrm{z}$ niedziałającymi w nim samoregulującymi mechanizmami rynkowymi, co rzutuje na ład ekonomiczny. Już w ramach Deklaracji Brundtland (1987) rolnictwu poświęcono wiele miejsca. Przede wszystkim jako sektorowi zapewniającemu bezpieczeństwo żywnościowe (równowaga społeczna), korzystającemu $\mathrm{z}$ naturalnych zasobów (równowaga ekologiczna) oraz będącemu źródłem dochodu dla znacznej liczby ludności świata (ład ekonomiczny). W szczególności dokument wskazuje, że zrównoważone rolnictwo nie może przyczyniać się do degradacji gleby (ibidem, 5.24), być zintegrowane z gospodarką leśną (ibidem, 5.71) oraz podnosić nie tylko przeciętną produktywność i dochody całego sektora, lecz przede wszystkim gospodarstw najmniejszych (ibidem, 5.90). W 1991 w Den Bosch powstała deklaracja oraz program działania na rzecz rolnictwa zrównoważonego i rozwoju obszarów wiejskich (ang. Sustainable Agriculture and Rural Development, SARD). Rok później w ramach przyjętej podczas Szczytu Ziemi w Rio de Janeiro Agendy 21 znalazł się rozdział 14., poświęcony właśnie tym zagadnieniom. Zgodnie z zapisami tego dokumentu głównym celem SARD jest zwiększenie produkcji żywności w sposób zrównoważony i poprawa bezpieczeństwa żywnościowego. Dla osiągnięcia tego celu wskazano szereg szczegółowych zaleceń, takich jak przegląd narzędzi polityki rolnej i ich transformacja w kierunku wspierania wielofunkcyjności rolnictwa; dywersyfikacja zatrudnienia na wsi; ochrona zasobów ziemi, wody oraz bioróżnorodności flory i fauny; zintegrowane zarządzanie nawożeniem i środkami ochrony roślin (Agenda 21, 14.4).

Rozwój rolnictwa zgodny z paradygmatem rozwoju zrównoważonego stał się szczególnie ważny dla krajów uprzemysłowionych, które wcześniej rozwój sektora rolnego opierały o model industrialny. Okazał się on jednak w dłuższej perspektywie zawodny. Proces ten opisują A. Czyżewski i Henisz-Matuszczak (2005). W pierwszej fazie wdrażania modelu industrialnego istotny wydatek stanowią nakłady na środki bieżące oraz koszty przekwalifikowania zasobów ziemi i pracy uwolnionych z rolnictwa. W dalszej kolejności niezbędne jest stosowanie instrumentów cenowych, rekompensujących na bieżąco wzrost zużycia pośredniego. Te z kolei implikują potrzebę interwencjonizmu handlowego dla obrony krajowej, niekonkurencyjnej cenowo produkcji, przed tańszymi towarami z importu. W dłuższej perspektywie koszty tej polityki (poprzez różnice w cenach krajowych i światowych) przerzucane są z podatników na konsumentów. Jednocześnie paradygmat industrialny zachęca do zwiększania produkcji, która w obliczu nieelastycznego popytu na żywność, prowadzi do powstawania nadwyżek, których koszt zagospodarowania spada na rząd. Ponadto, zgodnie $\mathrm{z}$ prawem malejących przychodów krańcowych, w każdym kolejnym cyklu produkcyjnym, wzrost intensyfikacji, koncentracji i mechanizacji upraw, przynosić musi mniejszy przyrost efektu. Zatem wydajność modelu industrialnego tłamszona jest zarówno od strony popytu jak i podaży, co ostateczne przesądza o jego zawodności w kwestii utrzymywania parytetu dochodowego rolników (A. Czyżewski, 2015). 
Jednocześnie industrialny model intensyfikacji rolnictwa nie jest zrównoważony, nie jest ani ekologiczny, ani ekoefektywny. Jest nieefektywny w wyżywieniu świata, szkodliwy dla środowiska i przyczynia się do utraty bioróżnorodności (Tittonell 2014, s. 54). Szczególnie w Europie model rolnictwa oparty na zbyt intensywnym nawożeniu, mechanizacji i koncentracji doprowadził do pogorszenia jakości środowiska naturalnego. Liczne przykłady negatywnego oddziaływania na środowisko naturalne w Europie przywołują Stoate i in. (2009). Autorzy w szczególności skupiają się na negatywnych skutkach rolnictwa industrialnego, takich jak zmniejszenie zróżnicowania wiejskiego krajobrazu, zmniejszenie bioróżnorodności obszarów wiejskich, porzucanie ziemi na obszarach peryferyjnych, degradacja gleby, eutrofizacja wód oraz nadmierna emisja gazów cieplarnianych. Jak wskazuje B. Czyżewski (2012, s. 166) „na pewnym etapie gospodarczego rozwoju kraju rozszerzają się funkcje sektora rolnego, wykraczając poza rolę dostawcy surowców rolnych". Z jednej strony wraz z zaspokojeniem podstawowych potrzeb żywnościowych ujawniają się potrzeby wyższego rzędu związane z dążeniem do zachowania dobrostanu środowiska i wyższą jakością produktów rolnych (A. Czyżewski, Kułyk 2011, s. 18). Z drugiej w obliczu nastawionego na eksploatację gospodarowania zasobami naturalnymi stają się one w coraz większym stopniu dobrami rzadkimi, przez co wzrasta ich relatywna wartość, określana względem zasobów tradycyjnie traktowanych jako nakłady w rolnictwie (szczególnie kapitału).

W odpowiedzi na wyżej nakreślone mechanizmy deprecjacji industrialnego modelu rolnictwa opracowano liczne modele alternatywne. Dla wszystkich nich punkt wyjścia stanowi paradygmat zrównoważonego rozwoju, jednakże akcentowane są różne jego elementy. Model rolnictwa wielofunkcyjnego (Roszkowska-Mądra 2009, s. 91-98; Wilkin 2010, s. 20-23; A. Czyżewski i Kułyk 2011, s. 17-20; Adamowicz 2004, s. 16-25) zwraca przede wszystkim uwagę na wypełnianie przez rolnictwo nie tylko produkcyjnych, ale również i pozaprodukcyjnych funkcji w postaci dostarczania dóbr i usług publicznych, w coraz większym stopniu dostrzeganych i docenianych przez społeczeństwa. Model rolnictwa społecznie zrównoważonego (Woś i Zegar 2002; Zegar 2007a, s. 284-285) ujmuje rolnictwo w sposób holistyczny, traktując je jako element systemu środowiskowego, nie dający się wpisać w ramy jednego ściśle określonego modelu. Jednocześnie istotę tego modelu stanowi działanie jednostek, które nie zagraża długookresowym interesom społeczności. Uwypuklenie społecznej sfery zrównoważenia rolnictwa odpowiada szczególnie specyfice wysokich zasobów pracy w rolnictwie polskim i kwestii rozdrobnienia agrarnego (Floriańczyk i Buks 2013, s. 38). Podobne bariery rozwoju napotyka również wiele innych państw, które przystapiły do UE po 2004 r. Model dualnego rozwoju rolnictwa (Matuszczak 2007; Kumar 1970) objawia się wspótistnieniem w ramach sektora rolnego dwóch subsektorów - rolnictwa komercyjnego i gospodarstw socjalnych lub jak wskazuje Zegar $(2007 \mathrm{~b}$, s. 6) rolnictwa industrialnego i zrównoważonego. Autor wskazuje ten model, jako najbardziej prawdopodobny w dającej się przewidzieć przyszłości.

W końcu pojawia się koncepcja zrównoważonej intensyfikacji rolnictwa. W tym opracowaniu poświęcone zostanie jej więcej miejsca, ze względu na powiązanie $\mathrm{z}$ analizowaną metodą operacjonalizacji, polegającą na pomiarze ekoefektywności. Zrównoważoną intensyfikację rozumieć można, jako "podniesienie wydajności produkcji (produkowanie więcej przy mniejszych zasobach), przy jednoczesnym minimalizowaniu i ograniczaniu wpływu na środowisko naturalne" (Deklaracja Warszawska 2011). Ponadto, zidentyfikować można cztery główne założenia tego procesu: (1) potrzeba zwiększenia 
produkcji żywności; (2) zwiększanie produkcji musi odbywać się poprzez wzrost plonów, gdyż zwiększanie areału użytków rolnych powoduje znaczące szkody środowiskowe; (3) bezpieczeństwo żywnościowe, wymaga poświęcenia takiej samej uwagi wzrostowi zrównoważenia środowiskowego, co wzrostowi produktywności; (4) wskazanie celów, bez jednoczesnego narzucania metod ich osiagnięcia (Garnett i in. 2013, s. 33). W kontekście UE szczególnie istotna wydaje się ostatnia z ww. przesłanek. Oznacza ona bowiem, że dla wdrożenia zasad zrównoważonej intensyfikacji niezbędny jest dobór określonej metody, zgodny ze specyfiką produkcji rolnej w danym państwie (Pretty 1997, s. 254; Tittonell 2014, s. 55). Badacze wprost wskazują, że działania mające na celu zrównoważoną intensyfikację na jednych obszarach oznaczać będą wzrost produktywności, na innych redukcję plonów i realokację zasobów czynnika ziemi (Garnett i in. 2013, s. 33; Godfray i Garnett 2014, s. 5). Ostatecznie w przypadku każdego rodzaju działań elementem warunkującym właściwy kierunek przemian, nie powodujących przekroczenia granicy degradacji środowiska jest postęp techniczny. Dlatego też jednym z podstawowych haseł zrównoważonej intensyfikacji jest sformułowanie „Więcej wiedzy na hektar!” (Buckwell i in., 2014). Dla wdrożenia tego postulatu niezbędne jest natomiast spełnienie trzech warunków: 1) "stworzenie" odpowiedniej wiedzy; 2) jej "dyfuzja" i wdrożenie do praktyki gospodarczej; 3) gruntowna zmiana dotychczasowego podejścia do modelu produkcji (Drygas i Nurzyńska 2015).

\section{Zrównoważony rozwój - krytyczna analiza podstaw konceptualnych}

$\mathrm{W}$ tej części rozważone zostaną problemy operacjonalizacyjne, wynikające z natury koncepcji zrównoważonego rozwoju. Za umowną datę narodzin tej idei przyjmuje się rok 1987, kiedy to opublikowany został raport Światowej Komisji ds. Środowiska i Rozwoju, zwanej również Komisją Brundtland, od nazwiska jej przewodniczącej Gro Harlem Brundtland. Umocnienie idei tej, jako wiodącej wśród teorii rozwoju, nastąpiło szczególnie po międzynarodowej konferencji ONZ „Środowisko i Rozwój” z 1992 roku (Rogall 2010, s. 17). Deklaracja Brundtland, zrównoważony rozwój definiuje jako: „taki, który zaspokaja potrzeby obecnych generacji, bez zmniejszania szans przyszłych pokoleń na zaspokojenie ich potrzeb" (Brundtland Report 1987). Choć jest to definicja najczęściej przytaczana (Howe 2005, s. 33) nie wyczerpuje ona pojemności znaczeniowej opisywanego zagadnienia. Wręcz przeciwnie, stanowi zazwyczaj punkt odniesienia dalszych rozważań. Słodowa-Hełpa (2010) zauważa, że w Polsce funkcjonuje co najmniej kilkadziesiąt, a w literaturze światowej kilkaset definicji zrównoważonego rozwoju. Nie ułatwia to ujęcia tej koncepcji w zwarte ramy analityczne. Datą przełomową dla ujednolicenia sposobu definiowania zrównoważonego rozwoju był rok 2002, kiedy to w Johhanesburgu odbył się Szczyt Ziemi, kontynuujący tematykę, jaka podjęta została 10 lat wcześniej w Rio de Janeiro. W podsumowującej szczyt deklaracji przyjęto ,zbiorową odpowiedzialność za rozwijanie wzajemnie powiązanych i wzmacniających się filarów zrównoważonego rozwoju - rozwoju ekonomicznego, społecznego i ochrony środowiska - na poziomie lokalnym, narodowym, regionalnymi i globalnym" (UN 2002). Na podstawie powyższej deklaracji sformułowano definicje wskazującą że rozwój zrównoważony to taki, który obejmuje sferę ekonomiczną, społeczną i środowiskową.

Choć osadzająca się na powyższych definicjach koncepcja wydaje się powszechnie akceptowana, nie oznacza to, że nie stanowi obiektu krytyki. Redclift (2005, s. 213-214) 
wskazuje na kilka wątpliwości związanych z definicją zawartą w Deklaracji Brundtland. Po pierwsze, nie uwzględnia ona faktu, że wraz z rozwojem gospodarczym ewoluują również potrzeby, zatem nie sposób przewidzieć, czy podejmowane obecnie kroki będa miały jakikolwiek związek z potrzebami przyszłych pokoleń. Po drugie, definicja nie uwzględnia zróżnicowania potrzeb w przestrzeni. Zakłada ona a priori, że zrównoważenie jest ważne dla wszystkich ludzi, choć jego postrzeganie różni się w poszczególnych krajach i kręgach kulturowych. Problematyczna staje się sytuacja, kiedy w wyniku różnic w postrzeganiu zrównoważenia, działania podejmowane w celu jego osiagnięcia są przeciwstawne. Po trzecie, definicja stanowi owoc dociekań naukowych, ignorując to jak zrównoważenie postrzegane jest w społeczeństwie. Dookreślenie zakresu zrównoważonego rozwoju w formie klasycznej triady celów częściowo rozwiązało te problemy, jednocześnie powodując jednak pojawienie się kolejnych. Wskazać można cztery szczególnie istotne zastrzeżenia (Buckwell i in. 2014, s. 30-31):

- kwestia wagi poszczególnych elementów - choć samo określenie „zrównoważony” sugeruje, że wszystkie elementy są równo ważne, nie jest to takie oczywiste. W zależności od kontekstu i sytuacji wyjściowej różne wymiary nie są traktowane jednakowo. Dostrzec można przewagę wymiaru środowiskowego i ekonomicznego nad społecznym, który jest zdecydowanie słabiej zbadany;

- „silne” kontra „słabe” zrównoważenie - zwolennicy pierwszej z koncepcji zakładają że dobra środowiskowe nie mogą być substytuowane przez inne formy kapitału, zatem gospodarka jest jedynie elementem większego systemu, który wyznacza jej granice. Słabe zrównoważenie zakłada możliwość niwelowania ubytków w zasobach kapitału naturalnego, kapitałem antropogenicznym;

- istnienie granic niezrównoważenia - stwierdzenie, że rozwój niezrównoważony, to taki który godzi $\mathrm{w}$ dobrobyt przyszłych pokoleń implikuje, że pewne działania powoduja nieodwracalne zmiany w środowisku. Istnieć musi zatem pewna granica niezrównoważenia gospodarki, po której przekroczeniu jakość środowiska naturalnego pogarsza się. Jej jednoznaczne określenie jest co najmniej utrudnione, jeżeli nie niemożliwe, co podważa całą ideę pomiaru stopnia zrównoważenia/niezrównoważenia;

- skala pomiaru zrównoważenia - różne problemy związane z niezrównoważonymi metodami gospodarowania ujawniać mogą się na różnych poziomach agregacji (globalnym, krajowym, regionalnym czy lokalnym). $\mathrm{Na}$ którym $\mathrm{z}$ nich powinny być prowadzone pomiary zrównoważenia? Dodatkowo działania zrównoważone lokalnie mogą być niezrównoważone globalnie i na odwrót (błąd złożenia).

Powyższe nieścisłości prowadzą do powstania jeszcze jednego zagrożenia. Ogólnikowe zdefiniowanie zrównoważonego rozwoju i teoretyczne braki tej koncepcji otwierają drogę do tego by stała się ona jedynie modnym terminem, rzucanym jedynie jako wyraz politycznej poprawności (Hopwood, Mellor, O’Brien 2005, s. 6). 


\section{Kategoria ekoefektywności (produktywności środowiskowej) w paradygmacie zrównoważonego rozwoju rolnictwa}

$\mathrm{Na}$ wstępie rozważań tych poczynić należy pewną uwagę dotyczącą społecznego wymiaru zrównoważonego rozwoju. Treść tego artykułu w zdecydowanej większości odnosi się do koncepcji ekoefektywność, która powiązana jest z ekologicznym wymiarem działalności rolniczej. Jest to świadomy zabieg, wynikający z szerszego upowszechnienia tej idei, w stosunku do koncepcji efektywności społecznej, a także odniesienia do ekoefektywności w teorii zrównoważonej intensyfikacji, stanowiącej bazę tych rozważań. Społeczny wymiar zrównoważonego rozwoju, jak już wcześniej zasygnalizowano jest niedoreprezentowany w badaniach. Wynika to m.in. z braku powszechnie akceptowalnych jego mierników. Dopóki niedostatki te nie zostaną zniwelowane, każdy miernik, próbujący ująć kwestię rozwoju w sposób kompleksowy, kwestie społeczne będą zbyt słabo akcentowane.

W świetle nakreślonych wcześniej wątpliwości narastających wokół sposobu definiowania rozwoju zrównoważonego, można spodziewać się także istnienia problemów operacjonalizacji i pomiaru realizacji tej koncepcji ${ }^{3}$. W opracowaniu tym w szczególności rozważone zostaną te, związane $\mathrm{z}$ wykorzystaniem do pomiarów ekoefektywności szacowanej metodą analizy obwiedni danych (DEA) ${ }^{4}$. Jest ona najczęściej stosowaną spośród metod pomiaru efektywności, szczególnie często wykorzystuje się ją również w badaniach efektywności rolnictwa (Emrouznejad i Guo-liang 2018). Jednakże większość z tych zastosowań dotyczy tradycyjnie rozumianej efektywności w wymiarze ekonomicznym, której forsowanie, w świetle paradygmatu zrównoważonego rozwoju jest postrzegane negatywnie. Zidentyfikować można tu swoisty paradoks. Jednoznacznie zdefiniowane i relatywnie łatwo mierzalne intensywność i produktywność, są generalnie krytykowane, podczas gdy niejednoznacznie definiowany i trudno mierzalny koncept zrównoważenia jest powszechnie wspierany (Buckwell i in. 2014, s. 26-35). Przyczyn takiego stanu rzeczy upatrywać można $\mathrm{W}$ praktykach zwiększania produktywności rolnictwa, które wprowadzane były bez uwzględnienia ładu społecznego i środowiskowego. Koncepcja zrównoważona intensyfikacja postuluje tymczasem zwiększanie produktywności w sposób przyjazny środowisku, a konstruktem metodycznym, niezwykle przydatnym w ilościowym opisie tego procesu jest właśnie produktywność środowiskowa, częściej w literaturze określana jako ekoefektywność ${ }^{5}$. Definiuje się ją jako stosunek

\footnotetext{
${ }^{3}$ Przykład niech stanowią problemy zidentyfikowane przy wykorzystaniu jednej z najczęściej stosowanych metod pomiaru zrównoważenia, jaką jest konstrukcja wskaźnika syntetycznego. Podejście to obarczone jest licznymi niedoskonałościami, takimi jak: (1) brak porównywalnych danych; (2) subiektywizm doboru mierników, wartości referencyjnych oraz sposobu ich agregacji i ważenia; (3) niejednoznaczny charakter mierników; (4) brak znajomości „optymalnej” wartości mierników (Borychowski, Staniszewski i Zagierski 2016, s. 33-34). Przegląd alternatywnych metod ilościowego opisu rozwoju gospodarczego znaleźć można m.in. w opracowaniu Cieślik (2008).

${ }^{4}$ Metoda obwiedni danych (ang. Data Envelopment Analysis, DEA), należy do granicznych metod wyznaczania efektywności, w których funkcja produkcji (granica możliwości produkcyjnych) określona zostaje w sposób nieparametryczny, na podstawie metod programowania liniowego. Szczegółowy opis metody znaleźć można w opracowaniu (Ćwiąkała-Małys i Nowak 2009, s. 201-230).

${ }^{5}$ Należy mieć świadomość, że pojęcia produktywności i efektywności nie są tożsame, jednakże dokładne wyjaśnienie tych różnic wykracza poza zakres niniejszego opracowania. Skrótowo wskazać można, że do oszacowania produktywności wystarczające są informacje odnośnie wielkości nakładów i efektów, zaś określenie
} 
wielkości produkcji rolniczej do wielkości zasobów naturalnych zużytych w tej produkcji (Rickard 2013, s. 49). Wskazać można liczne opracowania gdzie szacuje się ekoefektywność sektora rolnego (Turčeková i in. 2015; Lin i Fei 2015; Hoang i Rao 2010; Hoang i Coelli 2011; Ball i in. 2001; Kuosmanen 2014; Ball i in. 2005; Klepacki, Gołasa i Wysokiński 2016). Podejście to stanowi próbę ograniczenia problemów doboru wag i punktu odniesienia, a także różnych jednostek, w których wyrażone są nakłady i efekty działalności rolniczej. Pozwala na to zastosowanie metody DEA. Wykorzystuje ona programowanie liniowe, co pozwala na ustalenie wag poszczególnych zasobów przyrody używanych w procesie produkcji w sposób endogeniczny. Dodatkowo, są one ustalane indywidualnie dla każdej obserwowanej jednostki decyzyjnej (gospodarstwa lub sektora rolnego), w zależności od jej sytuacji wyjściowej (Picazo-Tadeo i in. 2012, s. 801). Rozwiazzanie to niesie pewne udoskonalenia także w zakresie wyboru punktu odniesienia, tak by był on osiagalny dla pozostałych jednostek. Bazując przy doborze na pojedynczym kryterium (np. produktywności czynnika ziemi) pomija się kwestie substytucyjności nakładów i efektów (np. wysoka produktywność czynnika ziemi może być wynikiem wysokich nakładów kapitału i pracy, których produktywności cząstkowe są odpowiednio niższe). W metodzie DEA punkt odniesienia wybierany jest na podstawie wszystkich zadanych nakładów i efektów, co pozwala uwzględnić kwestię ich substytucyjności. Metoda ta, wykorzystując odległości względne pozwala również na ominięcie problemu różnych jednostek w jakich wyrażone są nakłady i efekty oraz braku informacji cenowej, który jest szczególnie dotkliwy w przypadku niewycenianych przez rynek nakładów środowiskowych. Możliwe jest to dzięki zastosowaniu mechanizmu cen kalkulacyjnych (ang. shadow prices), które określane są na podstawie otrzymanej funkcji produkcji (Coelli i Prasada Rao 2005, s. 117).

W świetle powyższych spostrzeżeń wydawać by się mogło, że metoda DEA, czy generalnie ujęcie zrównoważonego rozwoju rolnictwa w kategoriach poprawy ekonomicznej, społecznej i środowiskowej produktywności, stanowi oczekiwane rozwiązanie problemu operacjonalizacji tej koncepcji. Niestety w istocie tak nie jest. Sama metoda DEA posiada co najmniej trzy znaczące niedostatki. Po pierwsze, jako metoda nieparametryczna nie uwzględnia czynnika losowego, klasyfikując wszelkie odchylenia od granicy możliwości produkcyjnych jako nieefektywność. Po drugie, badana grupa jednostek musi być jednolita, dążyć do maksymalizacji takiego samego zbioru efektów, działać w podobnych warunkach rynkowych i korzystać z tego samego zbioru nakładów (Hoang i Coelli 2011, s. 462). Po trzecie, podobnie jak w przypadku wszystkich metod syntetycznego pomiaru zrównoważonego rozwoju, wyniki badań są zależne od wykorzystanego do obliczeń zestawu nakładów ekonomicznych, ekologicznych i społecznych. Ponadto, liczba cech opisujących poszczególne wymiary rzutować może pośrednio na przyznaną tym wymiarom wagę. Biorąc pod uwagę fakt, że współcześnie zbiór nakładów warunkowany jest w głównym stopniu dostępnością danych, dojść możemy do sytuacji, w której o wadze danego wymiaru decyduje jego mierzalność, co utrwala prymat wymiaru ekonomicznego. Z technicznego punktu widzenia wymienić można jeszcze problemy sygnalizowane przez Byerlee i Murgaia (2001, s. 229-232). Piszą oni o możliwym braku wpływu kosztów niewycenianych przez rynek efektów zewnętrznych na decyzje ekonomiczne podmiotów oraz o różnicach w systemach produkcji (różnic 
strukturalnych, np. pomiędzy produkcją roślinną i zwierzęca), często nieuwzględnianych w badaniach.

W kwestii postrzegania zrównoważonego rozwoju przez pryzmat ekoefektywności również wskazać można pewne wątpliwości natury koncepcyjnej. Identyfikują je m.in. Lorek i Lorek (2016, s. 229), wskazując na: 1) trudności w określeniu co jest nakładem, a co efektem; 2) problematyczną agregacją; 3) problematyczną waloryzacją nakładów i efektów ekologicznych i społecznych; 4) obiekcje moralne przeciw wycenie wartości takich jak „zdrowie” czy „życie”; 5) wymienność pomiędzy kompletnością wskaźników i ich powiązaniem z systemem pojęć używanych przez decydentów. Choć omawiana metoda DEA pozwala na ominięcie części tych zastrzeżeń, związanych $z$ agregacją i waloryzacją nakładów ekologicznych i społecznych, pozostałe kwestie pozostają nierozstrzygnięte. Możliwość przyjęcia określonych cech alternatywnie, jako nakłady lub efekty, stanowi rozwinięcie zasygnalizowanego już problemu zmienności zestawu mierników zrównoważonego rozwoju. Kwestię wskazanych wątpliwości natury moralnej, odnieść można do problemu rozgraniczenia pomiędzy „silnym” i „słabym” zrównoważeniem. W badaniach analizujących ekoefektywność, wraz z zestawieniem nakładów kapitałowych z nakładami typu emisja gazów cieplarnianych czy zanieczyszczenie wód gruntowych przyjmuje się ,nieme” założenie o ich substytucji, co oznacza, że badania prowadzone są z perspektywy „słabej” wersji zrównoważenia. Przyjęcie tej perspektywy doprowadzić może w skrajnych przypadkach do wypaczenia idei zrównoważonego rozwoju. W szczególności, w sytuacji gdy analizowane jednostki zdecydują się na przyjęcie strategii poprawy efektywności w sposób nakładochłonny, zwiększając produkcję poprzez substytucję nakładów ekonomicznych, nakładami środowiskowymi. Zatem, by analiza $\mathrm{z}$ punktu widzenia ekoefektywności miała uzasadnienie niezbędne jest przyjęcie kolejnego założenia o istnieniu mechanizmów ograniczających nadmierną eksploatację środowiska. W Unii Europejskiej za narzędzia takie uznać można chociażby wymogi wzajemnej zgodności (ang. Cross-compliance). Założenie to prowadzi natomiast do kolejnej kwestii, dotyczącej granic niezrównoważenia. W analizach ekoefektywności, wyznaczona przez podmioty najbardziej produktywne funkcja produkcji, stanowiąca jednocześnie swoistą granice produktywności zasobów przyrody, nie odnosi się bezpośrednio do problemu faktycznej granicy wykorzystania tych zasobów, po której przekroczeniu zostaną one bezpowrotnie utracone. Opisuje ona raczej możliwy do osiagnięcia efekt, przy obecnie stosowanej kombinacji nakładów. Przyjąć zatem trzeba, że kombinacja ta reprezentuje poziom wykorzystania zasobów przyrody, nie przekraczający możliwości jej regeneracji. Rozstrzygnięcie czy jest tak w istocie leży już jednak nie w obrębie nauk ekonomicznych, lecz raczej przyrodniczych.

Ostatecznie, odnosząc się do ostatniego z przytoczonych argumentów, dotyczącego braku zrozumienia, a przez to i poparcia dla bardziej zaawansowanych wskaźników ekoefektywności, lepiej opisujących rzeczywiste metody produkcji, można powiedzieć, że podstawowy problem rozróżnienia rolnictwa industrialnego i zrównoważonego wyraża się również w kategoriach semantycznych. O ile industrialna ścieżka rozwoju rolnictwa określona może zostać „paradygmatem ilości”, o tyle model zrównoważony zasługuje na miano „paradygmatu jakości”, a dychotomia ta objawia się już na etapie doboru zmiennych opisujących dany model. Rolnictwo intensywne skupia się bowiem na ścisłych, mierzalnych parametrach, a ostateczny sukces ekonomiczny gospodarstwa mierzony jest wysokością wytworzonej nadwyżki pieniężnej. Do modelu zrównoważonego wprowadzone zostają natomiast zmienne typowo jakościowe. W tej sytuacji próba porównywania 
wyników ekonomicznych gospodarstw operujących według różnych modeli napotyka problem, że wyrażone są one niejako „w różnych jednostkach” (A. Czyżewski 2015, s. 16). Wykorzystanie narzędzi kojarzonych z paradygmatem industrialnym, $\mathrm{w}$ analizach $\mathrm{z}$ zakresu ekonomii zrównoważonego rozwoju może zatem przyspieszyć proces jej upowszechniania i uczynić jej założenia bardziej zrozumiałymi dla przedstawicieli szkoły ilościowej. Z drugiej strony nie do przecenienia jest dorobek szkoły tej w zakresie operacjonalizacji i modelowania zjawisk ekonomicznych. Na syntezie tej obie strony powinny zatem skorzystać.

\section{Podsumowanie}

Konkludując powyższe rozważania stwierdzić można, że:

- koncepcja zrównoważonego rozwoju już od momentu sformułowania, znalazła odzwierciedlenie $\mathrm{w}$ postulowanych kierunkach rozwoju rolnictwa, którego dotychczasowy, industrialny paradygmat bliski był osiagnięcia granic użyteczności, ze względu na generowane problemy ekonomiczne, społeczne i środowiskowe. Zaproponowano liczne koncepcje rozwoju sektora rolnego, sytuujące się w obrębie paradygmatu zrównoważonego rozwoju, takie jak rolnictwo wielofunkcyjne, społecznie zrównoważone czy dualne. Wśród powyższych wskazać można również koncepcję zrównoważonej intensyfikacji, postulującą zwiększanie wydajności produkcji przy jednoczesnym ograniczaniu negatywnego wpływu na środowisko naturalne;

- choć paradygmat zrównoważonego rozwoju jest już silnie ugruntowany w świadomości badaczy i społeczeństwa, identyfikowane są również pewne jego niedostatki teoretyczne rzutujące na możliwość jego wdrażania. W szczególności podnosi się problem określenia wag ekonomicznego, społecznego i środowiskowego wymiaru zrównoważonego rozwoju, substytucji zasobów przyrody kapitałem, identyfikacji granic rozwoju niezrównoważonego i błędu złożenia w badaniach;

- w nawiązaniu do koncepcji zrównoważonej intensyfikacji i zastrzeżeń wysuwanych względem paradygmatu zrównoważonego rozwoju, wskazać można kategorię ekoefektywności, szacowanej z wykorzystaniem metody DEA, jako jedną z potencjalnych metod operacjonalizacji ww. konstruktów teoretycznych. Wykorzystanie metody tej pozwala na ograniczenie problemów związanych z doborem wag i punktu odniesienia, a także różnych jednostek, w których wyrażone są nakłady i efekty działalności rolniczej. Jednocześnie, stosując opisywaną metodę przyjąć trzeba założenia o nieuwzględnianiu $\mathrm{w}$ badaniach czynnika losowego $\mathrm{i}$ homogeniczności badanej grupy podmiotów, a także o wymienności nakładów kapitałowych i środowiskowych oraz istnieniu instytucjonalnych ograniczeń nadmiernej eksploatacji zasobów ekologicznych. Jednocześnie, za jedną z najważniejszych zalet opisywanej metody uznać można swoistą syntezę „ilościowych” metod badawczych, z, jakościowym” sposobem pojmowania świata, stanowiącym istotę paradygmatu zrównoważonego rozwoju rolnictwa. 


\section{Literatura}

Adamowicz, M. (2004). Wielofunkcyjność rolnictwa jako podstawa przewartościowań w polityce rolnej (Multifunctionality of Agriculture as a Basic for Re-evaluation of Agricultural Policy). Wieś i Rolnictwo, 4, 9-30.

Allen, R.C. (2000). Economic Structure and Agricultural Productivity in Europe, 1300-1800, Review of Economic History, 3, 1-25.

Ball, E., Färe, R., Grosskopf, S., Zaim, O. (2005). Accounting for Externalities in the Measurement of Productivity Growth: the Malmquist Cost Productivity Measure. Structural Change and Economic Dynamics, 16, 374-394.

Ball, V.E., Färe, R., Grosskopf, S., Nehring, R. (2001). Productivity of the U.S. Agricultural Sector: The Case of Undesirable Outputs. New Developments in Productivity Analysis, January, 541-586.

Bank Światowy (2016). Updated National and Global Estimates of Distortions to Agricultural Incentives, 1955 to 2011. Pobrano 27 grudnia 2016 z: http://siteresources.worldbank.org/INTRES/Resources/4692321107449512766/Note_summarizing_core_updated_database_0613.pdf.

Borychowski, M., Staniszewski, J., Zagierski, B. (2016). Problemy pomiaru rozwoju zrównoważonego na przykładzie wybranych wskaźników (Problems of the Measuring of the Sustainable Development on the Examples of Selected Indicators). Roczniki Ekonomiczne Kujawsko-Pomorskiej Szkoły Wyższej Bydgoszczy, 9, 28-43.

Brundtland, G i in. (1987). Our common future. Pobrano 27 pażdziernika 2016 z: http://www.undocuments.net/our-common-future.pdf.

Buckwell, A. i in. (2014). Sustainable Intensification of European Agriculture A Review Sponsored by the RISE Foundation. The RISE Foundation, Bruksela.

Byerlee, D., Murgai, R. (2001). Sense and Sustainability Revisited: the Limits of Total Factor Productivity Measures of Sustainable Agricultural Systems. Agricultural Economics, 26, 227-236.

Cieślik, E. (2008). Wybrane alternatywne sposoby mierzenia poziomu rozwoju gospodarczego (Selected Alternative Methods of Measuring Economic Development). Equilibrium. Quarterly Journal of Economics and Economic Policy, 1(1-2), 145-160.

Coelli, T.J., Prasada Rao, D.S. (2005). Total Factor Productivity Growth in Agriculture: a Malmquist Index Analysis of 93 Countries, 1980-2000. Agricultural Economics, Supplement, 115-134.

Czyżewski, A, Kułyk, P. (2011). Dobra publiczne w koncepcji wielofunkcyjnego rozwoju rolnictwa; ujęcie teoretyczne i praktyczne (Public Goods in the Concept of Multifunctional Development of Agriculture; Theoretical and Practical Approach). ZN SGGW Problemy Rolnictwa Światowego, 11(2), 16-25.

Czyżewski, A. (2015). Teoriopoznawcze przesłanki rozwoju rolnictwa rodzinnego (Theoretical Prerequisites for the Development of Family Farming). W: A. Chlebicka (red.), Ekonomiczne mechanizmy wspierania $i$ ochrony rolnictwa rodzinnego w Polsce i innych państwach Unii Europejskiej, FAPA, Warszawa, 9-30.

Czyżewski, A., Henisz-Matuszczak, A. (2005). Makroekonomiczne uwarunkowania rolnictwa industrialnego i społecznie zrównoważonego. Refleksje na temat sprzężeń regulacyjnych i realnych (Macroeconomic Conditions of Industrial and Socially Sustainable Agriculture. Reflections on Control and Real-Life Couplings). W: Zegar, J.S. (red.), Koncepcja badań nad rolnictwem społecznie zrównoważonym. IERiGŻ, Warszawa, 53-71.

Czyżewski, B. (2012) Produktywność zasobów w rolnictwie w Polsce wobec paradygmatu zrównoważonego rozwoju (Resource Productivity in Polish Agriculture: Towards the Paradigm of Sustainable Development). Studia Ekonomiczne, 2, 165-188.

Czyżewski, B. (2013). Renty ekonomiczne w gospodarce żywnościowej w Polsce (Economic Rents in the Food Sector in Poland). Polskie Wydawnictwo Ekonomiczne, Warszawa.

Ćwiąkała-Małys, A., Nowak, W. (2009). Wybrane metody pomiaru efektywności podmiotu gospodarczego (Selected Methods for Measuring the Entitie's Economic Performance). Wyd. Uniwersytetu Wrocławskiego.

Deklaracja Warszawska dotycząca kluczowej roli Unii Europejskiej w rozwiązywaniu problemów żywnościowych świata (Warsaw Declaration on the Key Role of the European Union in Solving the Problems of Food Security in the World), Warszawa 2011. Pobrano 31 października 2016 Z: http://www.minrol.gov.pl/pol/content/ download/32537/180292/file/delaracja_warszawska_pl.pdf.

Drygas, M., Nurzyńska, I. (2015) Zrównoważona intensyfikacji - mit czy realna szansa? (Sustainable Intensification - Myth or a Real Chance?). W: Hardt L., Milczarek-Andrzejewska D. (red.), Ekonomia jest piękna? Wydawnictw Naukowe Scholar, Warszawa, 336-350.

Emrouznejad, A., Guo-liang, Y. (2018). A Survey and Analysis of the First 40 Years of Scholarly Literature in DEA: 1978-2016. Socio-Economic Planning Sciences, 61(1), 1-5. 
Floriańczyk, Z., Buks, J. (2013). Wyniki ekonomiczne gospodarstw rolnych a optymalny płodozmian (Economic Performance of Farms and Optimal Crop Rotation). Journal of Agribusiness and Rural Development, 4(30), 37-46.

Garnett, T., Appleby, M.C., Balmford, A., Bateman, I.J., Benton, T.G., Bloomer, P., Burlingame, B., Dawkins, M., Dolan, L., Fraser, D., Herrero, M., Hoffmann, I., Thornton, P.K., Toulmin, C., Vermeulen, S.J., Godfray, H.C.J. (2013). Sustainable Intensification in Agriculture: Premises and Policies, Science, 341(6141), 33-34.

Godfray, H.C.J., Garnett T., (2014), Food Security and Sustainable Intensification, Philosophical Transactions of the Royal Society B: Biological Sciences, 369(1639).

Hoang, V.-N., Coelli, T. (2011). Measurement of Agricultural Total Factor Productivity Growth Incorporating Environmental Factors: A Nutrients Balance Approach. Journal of Environmental Economics and Management, 62, 462-474.

Hoang, V.-N., Prasada Rao, D.S. (2010). Measuring and Decomposing Sustainable Efficiency in Agricultural Production: A Cumulative Exergy Balance Approach. Ecological Economics, 69, 1765-1776.

Hopwood, B., Mellor, M., O'Brien, G. (2005). Sustainable Development: Mapping Different Approaches. Sustainable Development, 13(1), 38-52.

Howe, K. S. (2005). Perspektywy rozwoju obszarów wiejskich w Europie: kwestia zrównoważenia. W: Zawalińska, K. (red.), Rozwój obszarów wiejskich. Doświadczenia krajów europejskich. Instytut Rozwoju Wsi i Rolnictwa Polskiej Akademii Nauk, Warszawa, 31-45.

Klepacki, B., Gołasa, P., Wysokiński, M. (2016). Efektywność emisji gazów cieplarnianych w rolnictwie Unii Europejskiej (Efficiency of greenhouse gas emissions in European Union agriculture). Wieś $i$ Rolnictwo, 3(172), 129-144.

Kumar, D. (1970). Technical change and dualism within agriculture in India. The Journal of Development Studies, 7(1), 50-59.

Lin, B., Fei, R. (2015). Regional differences of CO 2 emissions performance in China's agricultural sector: A Malmquist index approach. European Journal of Agronomy, 70, 33-40.

Lorek, E., Lorek, A. (2016). Ekoefektywność gospodarki warunkiem zielonego wzrostu i rozwoju zrównoważonego (Eco-efficiency of the economy - a condition for green growth and sustainable development). [w:] S. Czaja, A. Graczyk (red.), Ekonomia i Środowisko. Księga jubileuszowa Profesora Bogusława Fiodora. Wydawnictwo UE we Wrocławiu, Wrocław, 220-230.

Maddison, A. (2005). Measuring And Interpreting World Economic Performance 1500-2001, Review of Income and Wealth, 51(1), 1-35.

Matuszczak, A. (2007). Dualny rozwój rolnictwa i obszarów wiejskich (Dual development of agriculture and rural areas). W: Czyżewski, A. (red.), Uniwersalia polityki rolnej $w$ gospodarce rynkowej-ujęcie makro- $i$ mikroekonomiczne. Wyd. AE w Poznaniu, Poznań.

ONZ (2016). GDP and its breakdown at current prices in National currency, Pobrano 27 grudnia 2016 z: http://unstats.un.org/unsd/snaama/dnltransfer.asp?fID $=1$.

Picazo-Tadeo, A. J., Beltrán-Esteve, M., Gómez-Limón, J. A. (2012). Assessing eco-efficiency with directional distance functions. European Journal of Operational Research, 220, 798-809.

Poczta-Wajda A., (2017). Polityka wspierania rolnictwa a problem deprywacji dochodowej rolników w krajach o różnym poziomie rozwoju (Agricultural policy and income deprivation of farmers in countries with different levels of development), PWN, Warszawa.

Pretty J., N. (1997). The sustainable intensification of agriculture. Natural Resources Forum, 21(4), 247-256.

Ratajczak, M. (2000). Infrastruktura a wzrost i rozwój gospodarczy (Infrastructure and growth and economic development). Ruch prawniczy, ekonomiczny i socjologiczny, LXII, 4, 83-102.

Redclift, M. (2005). Sustainable development (1987-2005): an oxymoron comes of age. Sustainable development, 13(4), 212-227.

Rickard, S. (2015). Food security and climate change: The role of sustainable intensification, the importance of scale and the CAP. EuroChoices, 14(1), 48-53.

Rogall, H. (2010). Ekonomia zrównoważonego rozwoju: teoria i praktyka. Wydawnictwo Zysk i S-ka, Warszawa.

Roszkowska-Mądra, B. (2009). Koncepcje rozwoju europejskiego rolnictwa i obszarów wiejskich (The concepts of agricultural and rural development in the European Union). Gospodarka Narodowa, 10, 83-102.

Słodowa-Hełpa, M. (2010). Zrównoważony rozwój a konkurencyjność w wymiarze lokalnym (Sustainable development and local competitiveness). W: Zrównoważony rozwój lokalny. Warunki rozwoju regionalnego $i$ lokalnego. Tom I. Stowarzyszenie Naukowe - Instytut Gospodarki i Rynku, Zachodniopomorski Uniwersytet Technologiczny, Wydział Ekonomiczny, Szczecin.

Staniszewski, J. (2017). The economic and environmental productivity of agriculture in the process of development, Research Papers in Economics and Finance, 2(1), 7-18. 


\section{A. Czyżewski, J. Staniszewski}

Stoate C. i in. (2009). Ecological impacts of early 21st century agricultural change in Europe-a review. Journal of Environmental Management, 91(1), 22-46.

Tittonell, P. (2014). Ecological intensification of agriculture-sustainable by nature. Current Opinion in Environmental Sustainability, 8, 53-61.

Turčeková, N., Svetlanská, T., Kollár, B., Záhorský, T. (2015). Agri-Environmental Performance of EU Member states. Agris on-line Papers in Economics and Informatics, 4(4), 199-208.

United Nations (1992). Agenda 21. Pobrano 7 luty 2017 z: http://www.un-documents.net/our-common-future.pdf.

United Nations (2002). Agenda item 87(a) Environment and sustainable development: implementation of Agenda

21 and the Programme for the Further Implementation of Agenda 21. Pobrano z: http://www. earthsummit2002.org/resolution.pdf

Wilkin, J. (red.) (2010). Wielofunkcyjność rolnictwa: kierunki badań, podstawy metodologiczne i implikacje praktyczne (Multifunctionality of agriculture: directions of research, methodological bases and practical implications). Instytut Rozwoju Wsi i Rolnictwa Polskiej Akademii Nauk, Warszawa.

Woś, A., Zegar, J.S. (2002). Rolnictwo spolecznie zrównoważone (Socially sustainable agriculture). Instytut Ekonomiki Rolnictwa i Gospodarki Żywnościowej, Warszawa.

Zegar, J.S. (2007a). Społeczne aspekty zrównoważonego rozwoju rolnictwa (Social aspects of sustainable development of agriculture). Fragmenta Agronomica, 4(96), 282-298.

Zegar, J.S. (2007b). Przesłanki nowej ekonomiki rolnictwa (The rationale for new agricultural economics). Zagadnienia Ekonomiki Rolnej, 4, 5-27.

Do cytowania / For citation:

Czyżewski A. Staniszewski J. (2018). Dylematy operacjonalizacji paradygmatu zrównoważonego rozwoju rolnictwa z wykorzystaniem pojęcia ekoefektywności. Problemy Rolnictwa Światowego, 18(2), 44-56; DOI: 10.22630/PRS.2018.18.2.33

Czyżewski A. Staniszewski J. (2018). Dilemmas of the Operationalisation of the Sustainable Agriculture Development Paradigm with Eco-Efficiency Measures (in Polish). Problems of World Agriculture, 18(2), 44-56; DOI: 10.22630/PRS.2018.18.2.33 